\title{
CORRELATION BETWEEN PAIN AND POSTURAL DEVIATION IN INDIVIDUALS WITH HTLV-1
}

\author{
Naiane Araújo Patrício*, Maíra Carvalho de Macêdo**, Caroline Carneiro Landim Machado***, \\ Renata de Sousa Mota ${ }^{* * *}$, Abrahão Fontes Baptista*****, Katia Nunes Sá ${ }^{* * * * * *}$ \\ Autor correspondente: Katia Nunes Sá - katia.sa@bahiana.edu.br \\ * Physiotherapist, Master's Degree in Health Technology in EBMSP, Substitute Professor of Anatomy at UFBA, Member of \\ the CNPq Research Group "Dinâmica do Sistema Neuromuscoesquelético" \\ ** Physiotherapist, Master's Degree in Medicine and Human Health in EBMSP, PhD student, Member of the CNPq Research \\ Group "Dinâmica do Sistema Neuromuscoesquelético" \\ *** Physioterapy Undergraduate at EBMSP, Scientific Iniciation Program Sponsored by PIBIC/FAPESB, Member of the \\ CNPq Research Group "Dinâmica do Sistema Neuromuscoesquelético" \\ **** Physiotherapist, Master's Degree in Science of Human Motricity in UCB/RJ, PhD student in EBMSP, Member of the \\ CNPq Research Group "Dinâmica do Sistema Neuromuscoesquelético" \\ ***** Physiotherapist, PhD in Morphological Science in UFRJ, Associated Professor at UFBA; Member of the CNPq \\ Research Group “Dinâmica do Sistema Neuromuscoesquelético” \\ ****** PhD, professor at BAHIANA - School of Medicine and Public Health and at UcSal - Salvador University, Scientific \\ Communications Manager at BAHIANA. Revista Pesquisa em Fisioterapia editor-in-chief.
}

\begin{abstract}
Introduction: The myelopathy associated with HTLV ו (HAM/TSP) produces, among other problems, postural abnormalities and chronic pain that may affect quality of life and functional independency. Objective: To assess correlation between postural abnormalities and pain intensity in HAM/TSP individuals. Methods: A cross sectional study including probable and defined HAM/TSP according to the World Health Organization criteria. Participants were selected from the BAHIANA School of Medicine and Public Health Multidisciplinary Assistance and Research Individuals with HTLV Reference Center,

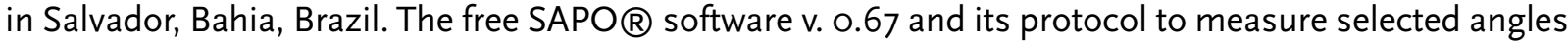
and body alignment on sagittal view were employed. To assess pain the Brief Pain Inventory (BPI) was applied. To test the correlation between variables the Spearman test was employed, with an alpha of $5 \%$ and $80 \%$ of power. Results: The sample was composed of 56 individuals. The majority of individuals (35; or $62,5 \%$ ) has been using walking support. A weak correlation was observed between postural deviation of body angle and reactive behavior on work activities $(p=0,05)$. Associations were found between body angle and lumbar pain $(p=0,05)$ and knee pain with ankle deviation $(p=0,02)$. Conclusion: Postural body deviation prevents difficulties to work and lumbar and knee pain were associated with deviations on body alignment and ankle angle.
\end{abstract}

Keywords: HTLV-1; Pain; Posture; Physiotherapy. 


\section{INTRODUCTION}

The HTLV-1 associated myelopathy or tropical spastic paraparesis (HAM/TSP) is a neurologic disturbance caused by human T-cell lymphotropic retrovirus type 1.(1) About $5 \%$ of individuals infected by HTLV-1 develop HAM/TSP. The HAM/TSP is characterized by slow and progressive demyelination that affects spinal cord causing lower limb spasticity and intense low back and leg pain. ${ }^{(2,3)}$ In Brazil, its prevalence is higher in Salvador, corresponding to $1.76 \%$ of the population, (4) being a costly public health concern, that causes great suffering among the affected.

The HAM/TSP health condition compromises posture ${ }^{(5)}$ and leads to higher intensity of pain. ${ }^{(6,7)}$ Several studies in other populations have been conducted to verify the association between pain and postural abnormalities and associations between headache and neck pain, and postural deviation have been found. ${ }^{(8,9)}$ People with HAM/TSP present high level of low back pain ${ }^{(7)}$ and postural deviation on sagittal view. ${ }^{(5)}$ However, it is not clear if there is a correlation between pain intensity, reactions to the pain and posture deviations in individuals with $\mathrm{HAM} / \mathrm{TSP}$.

The knowledge about postural causes of pain in $\mathrm{HAM} / \mathrm{TSP}$ condition may reduce pain intensity of mechanical origin with positive impact on quality of life of infected patients. Multidisciplinary teams could develop news exercise protocols to prevent and treat pain in this population. The aim of this study was to check correlation between postural abnormalities and pain intensity in individuals with HAM/TSP.

\section{METHODS}

This is a cross sectional study developed from July 2013 to December 2014 on individuals with HAM/ TSP from the BAHIANA School of Medicine and Public Health Multidisciplinary Assistance and Research Individuals with HTLV Reference Center, in Salvador, Bahia, Brazil.
The criteria of inclusion and probable diagnostic of HAM/TSP were defined as recommended by the World Health Organization. ${ }^{(10)}$ The possibility to stay for five minutes in a standing position, and the comprehension of the instructions and questionnaires were also employed as inclusion criteria. Individuals with other chronic diseases and under influence of factors and elements that could function as confounding variables were excluded, as evaluated by a neurologist from the Reference Center.

The sample size was estimated according to the clinical experience of researchers in this population. It was used an online free calculator (www.lee.dante. usp.br). An alpha of 0.5 was adopted, with a 5-degree standard deviation to 4 degrees of difference to be detected and a power of $80 \%$, which estimated a sample of 24 subjects per group.

The research project was previously submitted to Ethical Committee and approved according to resolution $466 / 12$ of the Brazilian Health National Council (registration number CAAE 13568213.8.0000.5544). Data was collected in a privative room by a trained team after the participants signed the Free and Informed Consent Term. After the study every participant has received information about the results in an annual meeting.

The posture was analyzed in the SAPO ${ }^{\circledR}$ software according to its protocol,(11) available in http://puig. pro.br/sapo/. Some selected angles were assessed as the system was applied on photographies of the sagittal view according to a previous study in this population. Being so, body alignment, trunk alignment, knee angle and ankle angle were under scrutiny. ${ }^{(7)}$ The anatomical points of interest were highlighted by semi Styrofoam balls $(25 \mathrm{~mm})$ attached to their bodies with double-sided tape.

Participants were instructed to wear gym clothes and to get naked. The privacy of the participants was preserved, as only authorized researchers had access to the photos and the data. Each individual was photographed in their right and left sagittal 
views. Their heads were parallel to the ground and their elbows were flexed in 90 degrees. As standard, a five minutes stance in a correct position was adopted, followed by relaxation and a rapid apnea. Following that, photos were then taken. The photos were transferred to a computer and the calibration was obtained by a graph paper that was fixed on the wall (with a distance of 20 centimeters between its two points).

To assess and analyze pain the Brief Pain Inventory was applied, ${ }^{(12)}$ specifically describing the worst pain in the past 24 hours and the mean of pain in the past 24 hours.

The predictor variables were postural deviation (body alignment, trunk alignment, knee and ankle angle) and the outcome variable was the intensity of pain. The analysis was performed in the Statistical Package for Social Science (SPSS) 17.0 version for Windows, employing the Spearman correlation (no normal distribution detected by KolmogorovSmirnov), considering an alpha of $5 \%$.

\section{RESULTS}

The sample contained 56 individuals, the majority of which were women (66.1\%), African descendants (91.1\%), and from low social class (39.2\%). The mean of age was $52.0 \pm 11.1$ years old, and time of diagnostic was 10.6 \pm 7.9 years. Mostly participants were eutrophic $(24.5 \pm 4.5 \mathrm{BMI})$. Mostly people required mobility aids $(62.5 \%)$ and took pain relief drugs $(26.1 \%)$. (table 1 ).

Table 1 - Sample Socio Demographic and Clinical Characteristics of Individuals with HAM/TSP, BAHIANA HTLV Reference Center, Salvador, Bahia, Brazil.

(continued)

\begin{tabular}{|c|c|c|}
\hline VARIABLES & $N=56$ & $N(\%)$ OR $M \pm S D$ \\
\hline \multirow{2}{*}{ Gender } & Female & 37 (66.1) \\
\hline & Male & 19 (33.9) \\
\hline Age (years old) & & $52.0 \pm 11.1$ \\
\hline Body Mass Index & & $24.5 \pm 4.5$ \\
\hline \multirow{4}{*}{ Skin Color } & Black & $27(48.2)$ \\
\hline & Mulatto & $24(42.9)$ \\
\hline & White & $4(7.1)$ \\
\hline & Yellow & $1(1.8)$ \\
\hline \multirow{5}{*}{ Social Class } & $A$ & $\mathrm{O}(0.0)$ \\
\hline & B & $4(7.2)$ \\
\hline & C & $29(51.8)$ \\
\hline & $D$ & $22(39.3)$ \\
\hline & E & $1(1.8)$ \\
\hline
\end{tabular}


Table 1 - Sample Socio Demographic and Clinical Characteristics of Individuals with HAM/TSP, BAHIANA HTLV Reference Center, Salvador, Bahia, Brazil.

\begin{tabular}{lcc}
\hline \multicolumn{1}{c}{ VARIABLES } & $\mathrm{N}=56$ & $\mathrm{~N}(\%)$ OR M \pm SD \\
\hline Intensity of Pain & & $4,88 \pm 3, \mathrm{O} 6$ \\
& & \\
Drugs for Pain Relief & No Drugs & $21(37.5)$ \\
& Muscle Relaxant & $23(41.1)$ \\
& Corticoids & $3(5.4)$ \\
& Antidepressant & $5(8.9)$ \\
Walking Aid Advices & Other & $4(7.1)$ \\
& No & $21(37.5)$ \\
& One Cane or One Crutch & $24(42.9)$ \\
\hline
\end{tabular}

M=Mean; SD=Standard Deviation; Social Class A and B= High, C=Meddle; D and E=Low (IBGE Parameters, Brazil).

No correlation was observed between the worst pain and mean of pain intensity and postural deviation in the past 24 hours (table 2). However, a weak correlation was observed between postural deviation of the body alignment angle and reactive behavior to perform work activities (table 3). It was also observed some association between mean of deviation with pain, specifically between body angle and lumbar pain and knee pain with ankle angle deviation (table 4).

Table 2 - Correlation between the worst pain and mean of pain in the past 24 hours, and postural deviation, in individuals with HAM/TSP from the BAHIANA HTLV Reference Center, Salvador, Bahia, Brazil

\begin{tabular}{lcccc}
\hline & WORSt PAIN (24 HOURS) & P & PAIN MEAN (24 HOURS) & P \\
\hline Trunk Right & 0.10 & 0.48 & 0.12 & 0.38 \\
Trunk Left & -0.12 & 0.40 & -0.11 & 0.42 \\
Body Right & 0.09 & 0.51 & -0.01 & 0.10 \\
Body Left & -0.16 & 0.24 & 0.05 & 0.72 \\
Knee Right & 0.08 & 0.55 & 0.05 & 0.71 \\
Knee Left & 0.13 & 0.36 & 0.08 & 0.58 \\
Ankle Right & -0.09 & 0.49 & -0.06 & 0.66 \\
Ankle Left & -0.11 & 0.44 & -0.17 & 0.21 \\
& & & & \\
\hline
\end{tabular}


Table 3 - Correlation between disruption of activities caused by pain in the past 24 hours and postural deviations, from the BAHIANA HTLV Reference Center, Salvador, Bahia, Brazil.

\begin{tabular}{|c|c|c|c|c|c|c|c|c|c|c|c|c|c|c|}
\hline & $\begin{array}{l}\text { GENERAL } \\
\text { ACTIVITY }\end{array}$ & $\mathbf{P}$ & HUMOR & $\mathbf{P}$ & WALKING & $\mathbf{P}$ & WORKING & $\mathbf{P}$ & ReLATIONShip & $\mathbf{P}$ & SLeEP & $\mathbf{P}$ & $\begin{array}{c}\text { ABILITY } \\
\text { TO } \\
\text { ENJOY } \\
\text { LIFE } \\
\end{array}$ & $\mathbf{P}$ \\
\hline $\begin{array}{l}\text { Trunk } \\
\text { Right }\end{array}$ & 0,12 & 0,38 & 0,01 & 0,99 & 0,19 & 0,17 & $\mathrm{O}, \mathrm{Ol}$ & 0,95 & 0,05 & 0,71 & 0,08 & 0,54 & 0,10 & 0,50 \\
\hline $\begin{array}{l}\text { Trunk } \\
\text { Left }\end{array}$ & $-0,86$ & 0,53 & $-0,16$ & 0,23 & $-0,04$ & 0,75 & $-0,19$ & 0,16 & $-0,06$ & 0,63 & $-0,06$ & 0,64 & 0,05 & 0,70 \\
\hline $\begin{array}{l}\text { Body } \\
\text { Right }\end{array}$ & 0,15 & 0,27 & 0,08 & 0,55 & 0,14 & 0,30 & $\mathrm{O}, \mathrm{O} 2$ & 0,86 & 0,14 & 0,31 & 0,11 & 0,40 & 0,18 & 0,20 \\
\hline $\begin{array}{l}\text { Body } \\
\text { Left }\end{array}$ & $-0,19$ & 0,16 & $-0,24$ & 0,08 & $-0,04$ & 0,72 & $-0,26$ & 0,05 & $-0,22$ & 0,11 & $-0,03$ & 0,83 & $-0,11$ & 0,42 \\
\hline $\begin{array}{l}\text { Knee } \\
\text { Right }\end{array}$ & 0,25 & $\mathrm{O}, \mathrm{O} 7$ & 0,26 & 0,06 & 0,22 & 0,11 & 0,21 & 0,13 & $-0,05$ & 0,71 & 0,03 & 0,80 & 0,03 & 0,81 \\
\hline $\begin{array}{l}\text { Knee } \\
\text { Left }\end{array}$ & 0,23 & O,O9 & 0,18 & 0,19 & 0,2 & 0,13 & 0,25 & 0,07 & O,05 & 0,73 & 0,09 & 0,51 & $-0,06$ & 0,69 \\
\hline $\begin{array}{l}\text { Ankle } \\
\text { Right }\end{array}$ & $-0,26$ & 0,06 & $-0,26$ & 0,52 & $-0,2$ & 0,15 & $-0,21$ & 0,13 & $-0,07$ & 0,60 & $-0,06$ & 0,63 & $-0,07$ & 0,62 \\
\hline $\begin{array}{c}\text { Ankle } \\
\text { Left }\end{array}$ & $-0,20$ & 0,15 & $-0,17$ & 0,20 & $-0,21$ & 0,12 & $-0,23$ & 0,09 & $-\mathrm{O}, \mathrm{O} 2$ & 0,90 & $-0,14$ & 0,30 & 0,12 & 0,38 \\
\hline
\end{tabular}

\section{Spearman's rho Test.}

Table 4 - Association between Pain Intensity and Postural Deviation, from the BAHIANA HTLV Reference Center, Salvador, Bahia, Brazil

\begin{tabular}{|c|c|c|c|c|c|c|c|c|c|c|c|}
\hline Pain & $\begin{array}{c}\text { Posture } \\
\text { Mean (SD) }\end{array}$ & $\mathbf{P}$ & Pain & $\begin{array}{c}\text { Posture } \\
\text { Mean (SD) }\end{array}$ & $\begin{array}{l}\text { Valor } \\
\text { P }\end{array}$ & Pain & $\begin{array}{c}\text { Posture } \\
\text { Mean (SD) }\end{array}$ & $\mathbf{P}$ & Pain & $\begin{array}{c}\text { Posture } \\
\text { Mean (SD) }\end{array}$ & $\mathbf{P}$ \\
\hline Neck (N) & & & $\begin{array}{l}\text { Lumbar } \\
\text { (N) }\end{array}$ & & & $\begin{array}{c}\text { Knee Right } \\
\text { (N) }\end{array}$ & & & $\begin{array}{c}\text { Knee Left } \\
\text { (N) }\end{array}$ & & \\
\hline & Trunk Right & & & Trunk Right & & & Trunk Right & & & Trunk Right & \\
\hline Yes (13) & $-2.39(6.33)$ & & Yes (37) & $-0.99(6.05)$ & & Yes (31) & $-1.14(6.15)$ & & Yes (30) & $-1.21(6.04)$ & \\
\hline No (42) & $-1.24(5.41)$ & 0.33 & No (18) & $-2.57(4.51)$ & 0.51 & No (24) & $-1.99(4.88)$ & 0.18 & No (25) & $-1.87(5.12)$ & 0.30 \\
\hline & Trunk Left & & & Trunk Left & & & Trunk Left & & & Trunk Left & \\
\hline Yes (13) & $-2.74(5.75)$ & & Yes (37) & $-1.26(5.52)$ & & Yes (31) & $-2.08(5.42)$ & & Yes (30) & $-2.10(5.37)$ & \\
\hline No (42) & $-1.60(5.28)$ & 0.43 & No (18) & $-3.12(4.95)$ & 0.55 & No (24) & $-1.60(5.40)$ & 0.68 & No (25) & $-1.60(5.45)$ & 0.93 \\
\hline & Body Right & & & Body Right & & & Body Right & & & Body Right & \\
\hline Yes (13) & $2.31(2.40)$ & & Yes (37) & $2.71(1.99)$ & & Yes (31) & $2.56(2.06)$ & & Yes (30) & $2.50(2.10)$ & \\
\hline No (42) & $2.36(1.97)$ & 0.28 & No (18) & $1.60(2.03)$ & 0.67 & No (24) & $2.07(2.06)$ & 0.80 & No (25) & $2.16(2.02)$ & 0.69 \\
\hline & Body Left & & & Body Left & & & Body Left & & & Body Left & \\
\hline Yes (13) & $1.40(1.95)$ & & Yes (37) & $1.42(2.19)$ & & Yes (31) & $1.40(2.13)$ & & Yes (30) & $1.43(2.20)$ & \\
\hline No (42) & $1.47(2.06)$ & 0.67 & No (18) & $1.53(1.67)$ & 0.05 & No (24) & $1.52(1.91)$ & 0.56 & No (25) & $1.48(1.81)$ & 0.25 \\
\hline
\end{tabular}


Table 4 - Association between Pain Intensity and Postural Deviation, from the BAHIANA HTLV Reference Center, Salvador, Bahia, Brazil

\begin{tabular}{|c|c|c|c|c|c|c|c|c|c|c|c|}
\hline Pain & $\begin{array}{l}\text { Posture } \\
\text { Mean (SD) }\end{array}$ & $\mathbf{P}$ & Pain & $\begin{array}{l}\text { Posture } \\
\text { Mean (SD) }\end{array}$ & $\begin{array}{l}\text { Valor } \\
\text { P }\end{array}$ & Pain & $\begin{array}{l}\text { Posture } \\
\text { Mean (SD) }\end{array}$ & $\mathbf{P}$ & Pain & $\begin{array}{l}\text { Posture } \\
\text { Mean (SD) }\end{array}$ & $\mathbf{P}$ \\
\hline & Knee Right & & & Knee Right & & & Knee Right & & & Knee Right & \\
\hline Yes (12) & $1.70(11.76)$ & & Yes (36) & $4.07(11.42)$ & & Yes (30) & $5.57(11.16)$ & & Yes (29) & $5.42(11,67)$ & \\
\hline \multirow[t]{2}{*}{ No (42) } & $4.04(11.15)$ & 0.73 & No (18) & $2.42(11.04)$ & 0.91 & No (24) & $0.95(10.97)$ & 0.92 & No (25) & $1.32(10,46)$ & 0.65 \\
\hline & Knee Left & & & Knee Left & & & Knee Left & & & Knee Left & \\
\hline Yes (13) & $3.60(14.66)$ & & Yes (37) & $6.27(13.45)$ & & Yes (31) & $6.01(14.03)$ & & Yes (30) & $6.81(14.08)$ & \\
\hline \multirow[t]{2}{*}{ No (42) } & $5.12(12.02)$ & 0.46 & No (18) & 1.68(10.18) & 0.11 & No (24) & $3.15(10.45)$ & 0.14 & No (25) & $2.31(10.21)$ & 0.10 \\
\hline & Ankle Right & & & Ankle Right & & & Ankle Right & & & Ankle Right & \\
\hline Yes (13) & $83.83(6.95)$ & & Yes (37) & $82.73(6.28)$ & & Yes (31) & $82.01(5.79)$ & & Yes (30) & $82.09(6.06)$ & \\
\hline \multirow[t]{2}{*}{ No (42) } & $82.99(6.13)$ & 0.48 & No (18) & $84.14(6.35)$ & 0.67 & No (24) & $84.72(6.67)$ & 0.59 & $\mathrm{No}(25)$ & $84.51(6.39)$ & 0.87 \\
\hline & Ankle Left & & & Ankle Left & & & Ankle Left & & & Ankle Left & \\
\hline Yes (13) & $83.83(6.35)$ & & Yes (37) & $83.27(7.04)$ & & Yes (31) & $83.04(7.42)$ & & Yes (30) & $82.58(7.59)$ & \\
\hline No (42) & $83.58(6.81)$ & 0.53 & No (18) & $84.38(5.87)$ & 0.32 & No (24) & $84.40(5.55)$ & 0.12 & No (25) & $84.90(5.17)$ & 0.02 \\
\hline
\end{tabular}

Student T Test.

\section{DISCUSSION}

The present study observed some correlations and associations between postural abnormalities with pain intensity and reactive behavior in individuals with HAM/TSP. Postural body deviation causes difficulty to work and lumbar and knee pain were associated with deviations on body alignment and ankle angle.

Difficulty to work in people with high intensity of pain is recognized in different studies and justify the importance of laboral gymnastics. ${ }^{(13,14)}$ However, in the present study, the alteration of body angle was correlated with difficulty to work. In spite of this random finding, psychological body alignment have been pointed as a cause of this behavior. DíazArribas, based on the Godelieve Denys-Struyf method, (15) showed association between different body segment alignments with different behaviors and how it is possible that a change of posture may have a positive impact on behavior. Occupations with higher mechanical workload require a lot from the body, taking a toll on work motivation. ${ }^{(16)}$ The lower socioeconomical classes, such as those presented in this study's sample, are usually employed in high mechanical workload occupations. ${ }^{(17)}$

Knee pain was associated with alignment of the knee, and with ankle angles too. It was expected that an articulation that receives high loads because it is the intermediate articulation of the lower limb presented more pain intensity. ${ }^{(18)}$ It was also expected that compensatory attitudes would be taken to relieve knee pain. In standing position the lower limb is in a kinetic closed chain. Reducing ankle angle is a comprehensive reaction in this situation. We might also expect the hip angular to be changed, ${ }^{(19)}$ but it was not found. However, trunk angle was associated with knee pain. It is possible that abnormal posture and spasticity on hip muscles may be affect by this expected compensation, reducing local reaction and transferring the load to the spinal supra segments. It has been showed that hip muscles are more affected in this clinical situation. ${ }^{(4,20)}$ 
Trunk deviation and lumbar pain is an expected association. Postural mechanic approaches normally expect to find relief of pain with charge reduction by realignment of body segments. ${ }^{(21)}$ There are several positive answers by postural reeducation of many health conditions ${ }^{(22)}$ and specific exercises for people with HAM/TSP. ${ }^{(23,24)}$

Trying to understand postural misalignment and pain in patients with HTLV, the findings suggest a lower ratio of anterior trunk displacement and low back pain. The low back pain group displayed a more "posteriorized" body as seen from the left profile in comparison with the group without low back pain. In contrast, on the same examination in the same angle of the right profile, the body tended to move above alignment even if there was no significant statistical difference between the group with or without the low back pain. These findings can be explained by the rotation to the left of the trunk, which may create the impression of a posterior alignment of the trunk in the left profile. Indeed it is understood the two-dimensional methods inability to identify the body misalignment in the transverse plane. ${ }^{(18)}$ Another explanation for this trend is that the small anterior body alignment would be related to a reduced need to activate the paraspinal muscles and as the body moved backwards, it caused the overload on the joint in the lower back which minimized the pain in the area.

The second result can show that the group with pain in the left knee has a small angle ankle. This reduction may be linked to a tendency of bending the knees, especially the left knee, although there is no significant statistical difference, which results in uneven distribution of body weight leading to an overload in the contralateral leg. ${ }^{(22)}$ Thus, it is concluded that these deviances can clarify the presence of pain specifically in the left knee.

The present study has limitations regarding assessment only on sagittal views in a static position in an postural condition lacking stability. Future studies needs to follow symptoms and postural alignment by the time employing dynamic systems.
We can conclude that postural body deviation prevents difficulty to work and lumbar and knee pain were associated with deviations of body alignment and ankle angle. In light of these results, postural reeducation and balance training by physiotherapy may help people with HTLV-1 to relieve mechanicalrelated pain.

\section{REFERENCES}

1. Gessain A, Vernant JC, Maurs L, Barin F, Gout O, Calender A, De Thé G. Antibodies to human T-lymphotropic virus type-l in patients with tropical spastic paraparesis. Lancet. 1985; (24):407-410.

2. Dourado I, Alcantara LC, Barreto ML, Da Gloria Teixeira M, Galvão-Castro B. HTLV-I in the general population of Salvador, Brazil: a city with African ethnic and sociodemographic characteristics. J Acquir Immune Defic Syndr. 2003; 34(5):527-531.

3. Gessain A, Cassar O. Epidemiological Aspects and World Distribution of HTLV-1 Infection. Front Microbiol. 2012;3:388. doi:10.3389/ fmicb.2012.00388.

4. Macêdo MC, Baptista AF, Sá KN, GalvãoCastro B, Duarte EF, Patrício N, Kruschewisky R, Andrade Filho AS. Postural profile of individuals with HAM/TSP. Brazilian Journal of Medicine and Human Health. 2013; 1(2):99-110.

5. Mendes SMD, Baptista AF, Sá KN, Andrade DCA, Otero GG, Cavalcanti JZ. Prevalence and characterization of pain in HTLV-1 carriers [Master's Dissertation]. Salvador: Bahia School of Medicine and Public Health - Bahia Foundation for the Development of Science; 2010.

6. Netto EC, Brites C. Characteristics of Chronic Pain and Its Impact on Quality of Life of Patients With HTLV-l-Associeted Myelopathy / Tropical Spastic Paraparesis (HAM/TSP) Clin J Pain. 2011; 27(2):131-135.

7. Dolphens M, Cagnie B, Coorevits P, Vanderstraeng G, Cardon G, D'hooge R, Danneels L. Sagittal Standing Posture 
and Its Association with Spinal Pain. Spine.2012;37(19):1657-1666.

8. Morris PG, Larson K, Klaus KM, Oatls CA. Incidence of Common Postural Abnormalities in the Cervical, Shoulder, and Thoracic Regions and Their Association with Pain in Two Age Groups of Healthy Subjects. Phys Ther. 1992;72(6):425-32.

9. Mochizuki L, Amadio AC. As funções do controle postural durante a postura ereta. Rev. Fisioter. Univ. São Paulo. 2003;10(1):7-15.

10. Castro-Costa CM, Araujo AQ, Barreto MM, Takayanagui OM, Sohler MP, da Silva EL, et al. Proposal for diagnostic criteria of tropical spastic paraparesis/HTLV-I-associated myelopathy (TSP/HAM). AIDS Res Hum Retroviruses. 2006;22(10):931-5.

11. Ferreira EA, Duarte M, Maldonado EP, Burke TN, Marques AP. Postural assessment software (PAS/SAPO): Validation and reliabiliy. Clinics. 2010;65(7):675-681

12. Memória CM, Yassuda MS, Nakano EY, Forlenza OV. Brief screening for mild cognitive impairment: validation of the Brazilian version of the Montreal cognitive assessment. Int J Geriatr Psychiatry. 2013;28(1):34-40.

13. Dolphens M, Cagnie B, Coorevits P, Vanderstraeng, Cardon G, D'hooge R, Danneels L. Sagittal Standing Posture and Its Association with Spinal Pain. Spine.2O12;37(19):1657-1666.

14. Santos GV, Maranhão ASV, Goes BT, Mota RS, Baptista AF, Sá KN. Pain assessment through the brief pain inventory in a low socioeconomic level population. Rev Dor. 2015;16(3):190-4

15. Díaz Arribas MJ, Ramos SM, Pardo HP, López CJ, Angulo CT, Ortega MP, Astasio AP. Effectiveness of the Physical Therapy Godelive Denys-Struyf Method for Nonspecific Low Back Pain Primary Care Randomized Control Trial. Spine. 2009;34(15):1529-38.

16. Macêdo MC, Baptista AF, Galvão-Castro B, Duarte EF, Patrício NA, Kruchewsky RA et al. Impacto dos desvios posturais na qualidade de vida de indivíduos com PET/MAH. Rev. Bras. Neurol. Psiquiatr.2O13;7(54):54-67.

17. Martins JVP, Baptista AF, Araujo AQ. Quality of life in patients with HTLV I Associated Myelopathy /Tropical Spastic Paraparesis: A Cross-sectional study in a Brazilian reference center. Arquivos de Neuro-Psiquiatria. 2012;9:257-261.

18. Morris PG, Larson K, Klaus KM, Oatls CA. Incidence of Common Postural Abnormalities in the Cervical, Shoulder, and Thoracic Regions and Their Association with Pain in Two Age Groups of Healthy Subjects. Phys Ther. 1992;72(6):425-32.

19. Souza JA, Pasinato F, Corrêa ECR, da Silva AMT. Global Body and Plantar Pressure Distribution in Individuals with and without Temporomandibular Disorder: A Preliminary Study. J Manipulative Physiol Ther. 2014;37(6):407-414.

2O. Franzoi AC, Araújo AQ. Disability profile of patients with HTLV-lassociated myelopathy/ tropical spastic paraparesis using the Functional Independence Measure (FIM). Spinal Cord. 2005;43(4):236-240.

21. Umphred DA, El-Din D. Introdução à reabilitação neurológica. In: Umphred DA, editor. Fisioterapia Neurológica. $4^{\mathrm{a}}$ ed. Barueri: Manole; 2004. p. 3-31.

22. Mochizuki L, Amadio AC. As funções do controle postural durante a postura ereta. Rev. Fisioter. 2003;10(1):7-15.

23. Lannes P, Neves MAO, Machado DCD, Miana LC, Silva JG, Basto VHV. Tropical Spastic Paraparesis Myelopathy associated to HTLV-I virus: possible physiotherapy strategies to motor rehabilitation. Rev. Neurociênc. 2006;14(3):153160.

24. Sá KN, Macêdo MC, Andrade RP, Mendes SD, Martins JV, Baptista AF. Physiotherapy for T-Lymphotropic vírus 1-associated myelopathy: review of the literature and future perspectives. J Multidiscip Healthc. 2015;(8):117-125. 